\title{
p53-dependent Ceramide Response to Genotoxic Stress
}

\author{
Ghassan S. Dbaibo, ${ }^{\star \star \| \star \star}$ Marina Y. Pushkareva, ${ }^{\S}$ Rima A. Rachid, ${ }^{\Uparrow}$ Nejemie Alter, ${ }^{\star}$ Miriam J. Smyth, ${ }^{\ddagger \S \|}$ Lina M. Obeid, ${ }^{\S \S}$ \\ and Yusuf A. Hannun $¥ \S$ \\ $*$ Department of Pediatrics, ${ }^{\ddagger}$ Department of Internal Medicine, and ${ }^{\S}$ Department of Cell Biology, Duke University Medical Center,

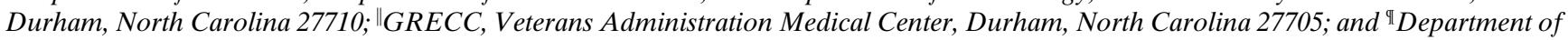 \\ Pediatrics and **Department of Biochemistry, American University of Beirut, Beirut, Lebanon
}

\begin{abstract}
Both $\mathrm{p} 53$ and ceramide have been implicated in the regulation of growth suppression. 553 has been proposed as the "guardian of the genome" and ceramide has been suggested as a "tumor suppressor lipid." Both molecules appear to regulate cell cycle arrest, senescence, and apoptosis. In this study, we investigated the relationship between $\mathrm{p} 53$ and ceramide. We found that treatment of Molt-4 cells with low concentrations of actinomycin D or $\gamma$-irradiation, which activate p53-dependent apoptosis, induces apoptosis only in cells expressing normal levels of p53. In these cells, p53 activation was followed by a dose- and time-dependent increase in endogenous ceramide levels which was not seen in cells lacking functional p53 and treated similarly. Similar results were seen in irradiated L929 cells whereby the p53-deficient clone was significantly more resistant to irradiation and exhibited no ceramide response. However, in p53-independent systems, such as growth suppression induced by TNF- $\alpha$ or serum deprivation, ceramide accumulated irrespective of the upregulation of $\mathrm{p} 53$, indicating that $\mathrm{p} 53$ regulates ceramide accumulation in only a subset of growth-suppressive pathways. Finally, ceramide did not increase p53 levels when used at growth-suppressive concentrations. Also, when cells lacking functional p53, either due to mutation or the expression of the E6 protein of human papilloma virus, were treated with exogenous ceramide, there was equal growth suppression, cell cycle arrest, and apoptosis as compared with cells expressing normal p53. These results indicate that p53 is unlikely to function "downstream" of ceramide. Instead, they suggest that, in situations where p53 performs a critical regulatory role, such as the response to genotoxic stress, it functions "upstream" of ceramide. These studies begin to define a relationship between these two pathways of growth inhibition. (J. Clin. Invest. 1998. 102: 329-339.) Key words: ceramide - sphingolipids - p53 • apoptosis
\end{abstract}

Marina Y. Pushkareva's current address is the Liposome Corporation, Princeton, NJ.

Address correspondence to Yusuf A. Hannun, Department of Biochemistry, Medical University of South Carolina, 171 Ashley Ave., Charleston, SC 29475. Phone: 843-792-4321; FAX: 843-7924322; E-mail: hannun@musc.edu

Received for publication 11 July 1997 and accepted in revised form 24 April 1998.

The Journal of Clinical Investigation

Volume 102, Number 2, July 1998, 329-339

http://www.jci.org

\section{Introduction}

During the past decade the tumor suppressor p53 became one of the most studied molecules in cancer research (1-3). A high frequency of mutations of the p53 gene is found in most human cancers (4), and in those tumors in which p53 itself is not mutated other factors may modulate its function to render it inactive. Examples include the expression of viral oncoproteins such as E6 of human papillomaviruses (HPVs) ${ }^{1}$ or overexpression of the human oncoprotein MDM2 $(5,6)$. High risk HPVs which are associated with an increased risk of developing cervical cancer express an E6 protein which binds to p53 and induces its degradation via the ubiquitin pathway $(7,8)$. Functionally, these cells become p53-deficient. On the other hand, MDM2 appears to participate in a negative feedback pathway activated by p53 (9-12).

p53 accumulates in response to genotoxic damage which occurs after exposure to chemotherapeutic agents, gamma irradiation, or ultraviolet irradiation $(2,13,14)$. Additionally, p53 shows a severalfold increase in its transcriptional activity in senescent compared with young cells (15). When upregulated, p53 appears to produce growth suppression and to participate in DNA repair by serving three essential functions. First, p53 plays an important role in the regulation of the cell cycle where its upregulation results in the arrest of the cell in the G1 phase (13). Second, p53 upregulation can drive the cell towards apoptosis $(16,17)$. Third, p53 appears to be involved in DNA repair (18-20). The integrity of these cellular defense functions is crucial for maintenance of an intact genome and, therefore, p53 has been called the "guardian of the genome" (21).

The mechanisms by which p53 exerts its functions remain poorly understood. p21 (WAF1/Cip1), a p53-inducible gene product, has been suggested as a mediator of some of the effects of p53 $(22,23)$. p21 was found to be an inhibitor of $G_{1}$ cyclin-dependent protein kinases which phosphorylate the retinoblastoma protein $(\mathrm{Rb})$ and related family members (24) leading to a $G_{0} / G_{1}$ arrest of the cell cycle (25). However, p21 was found to have no essential role in transducing the apoptotic effects of p53 as mice lacking p21 develop normally with no defects in apoptosis although they had compromised cell cycle arrest after DNA damage $(26,27)$. Additionally, recent studies have shown that p53-dependent apoptosis occurs in the absence of new RNA or protein synthesis and may be mediated, instead, by transcriptional repression (28-30). Therefore, factors other than p21 must be involved in transducing the effect of p53 on apoptosis.

The sphingolipid breakdown product, ceramide, has been shown to exert potent growth suppressive effects in a variety of

1. Abbreviations used in this paper: ASmase, acid sphingomyelinase; DAG, diacylglycerol; HPV, human papillomavirus; PARP, poly(ADP) ribose polymerase; $\mathrm{Rb}$, the retinoblastoma protein. 
cell types (31). These effects have been shown to be due to the ability of ceramide to induce differentiation (32), $\mathrm{Rb}$ dephosphorylation with resultant cell cycle arrest in $\mathrm{G}_{0} / \mathrm{G}_{1}(33,34)$, apoptosis (35), and senescence (36). Inducers of ceramide accumulation include TNF- $\alpha(35,37)$, Fas ligation $(38,39)$, serum deprivation (33), and ionizing irradiation (40). After stimulation with one of these inducers, cellular levels of ceramide increase over several hours. Subsequently, cells show morphology typical of apoptosis with internucleosomal DNA fragmentation and cleavage of poly(ADP) ribose polymerase (PARP) to signature apoptotic fragments $(41,42)$. Exogenous cell-permeable synthetic ceramides have been shown to reproduce these same effects when added to cells growing in culture. Thus, ceramide has been suggested to be a "tumor suppressor lipid" $(43,44)$.

The striking similarities between the biological functions of p53 and ceramide prompted us to examine whether they were mutually dependent. Thus, p53 may act "downstream" of ceramide and may be required for ceramide function, p53 may act "upstream" of ceramide and may be required for ceramide generation, or p53 and ceramide may define independent pathways of growth suppression. In this study we find that the chemotherapeutic agent actinomycin $\mathrm{D}$ and $\gamma$-irradiation cause ceramide accumulation and cell death in a p53-dependent manner. Additionally, we find that ceramide does not upregulate p53 expression and that p53 is not required for ceramide-induced effects. Taken together, these data suggest that p53 functions upstream of ceramide accumulation in p53dependent pathways. This work begins to define the sequence of events in growth inhibition pathways regulated by p53 and ceramide.

\section{Methods}

Cell culture and cell death assays. The human leukemia cell lines HL-60, U937, and Molt-4 and the murine fibroblast cell line L929 were obtained from American Type Culture Collection. The leukemia cell lines were grown in RPMI 1640 supplemented with 10\% FBS and buffered with sodium bicarbonate. L929 fibroblasts were grown in Dulbecco's modified essential medium supplemented with $10 \%$ FBS and buffered with Hepes.

Molt-4-LXSN, Molt-4-E6, L929-LXSN, and L929-E6 cell lines were derived following a previously described procedure using retrovirally mediated gene transfer (45). Retroviral constructs were a kind gift from Dr. Denise Galloway (University of Washington, Seattle, WA). Stable transfectants were isolated after $14 \mathrm{~d}$ of selection with G418 $500 \mu \mathrm{g} / \mathrm{ml}$. Cells were maintained in media supplemented with G418. Experiments were done in the absence of G418. Doubling times for the Molt-4 and L929 cell lines were 18-20 and 20-22 h, respectively.

Cell death was assayed by uptake of trypan blue for leukemia cells and crystal violet staining for L929 cell lines. For crystal violet staining, cells were washed with PBS, stained with $0.5 \%$ crystal violet for $10 \mathrm{~min}$, washed twice with water and once with $33 \%$ acetic acid. Samples were read at $600 \mathrm{~nm}$.

Apoptosis was verified using flow cytometry or assaying for cleavage of PARP on Western blotting using a rabbit polyclonal antiserum $(41,46)$ as described below.

Ceramide synthesis and metabolism. D-erythro- $\mathrm{C}_{6}$-Ceramide $\left(\mathrm{C}_{6}\right.$ ceramide) synthesis and its metabolism in target cells have been described $(34,47,48)$.

Western blotting for p53 and Rb. Western blotting was done as described (34). Briefly, cell lysates were prepared from $2 \times 10^{6}$ cells using the following buffer: $1 \%$ SDS, $5 \%$ (vol/ $/ \mathrm{vol}$ ) glycerol, $1.5 \%$ (vol/ vol) 2-mercaptoethanol, $20 \mathrm{mM}$ Tris, $\mathrm{pH}$ 7.4. The lysates were boiled for $10 \mathrm{~min}$ or to solubilization, and aliquots were removed for determination of protein concentration (BioRad assay). Equal amounts of total protein $(100-150 \mu \mathrm{g})$ were run on a $10 \%$ SDS gel and then transferred to nitrocellulose paper. Equivalent loading was checked by Ponceau S staining of the blot. Molt-4 lysates were probed with anti-human wild-type p53 antibody (Upstate Biotechnology Inc. or Ab6 from Oncogene Science), whereas L929 cell lysates were probed with PAb 122 which recognizes both human and murine p53 (PharMingen).

Cell cycle studies. Flow cytometry was performed on $2 \times 10^{6}$ Molt- 4 cells. Cells were harvested by centrifugation, washed, and then resuspended in $1 \mathrm{ml}$ PBS. Cells were fixed in $80 \%$ ethanol at $-20^{\circ} \mathrm{C}$. On the day of analysis, cells were stained with propidium iodide $(100 \mu \mathrm{g} / \mathrm{ml})$ in the presence of RNase $(20 \mu \mathrm{g} / \mathrm{ml})$ and flow cytometry was performed using a FACStarplus ${ }^{\circledR}$ flow cytometer (Becton Dickinson). Apoptotic cells contained $<2$ N DNA.

Ceramide measurement. Lipids were collected according to the method of Bligh and Dyer (49). Ceramide was measured with a modified diacylglycerol (DAG) kinase assay $(32,50)$ using external ceramide standards as described (34). Briefly, $80 \%$ of the lipid sample was dried under $\mathrm{N}_{2}$. The dried lipid was solubilized in $20 \mu \mathrm{l}$ of an octyl- $\beta$-D-glucoside/dioleoyl phosphatidylglycerol micellar solution (7.5\% octyl- $\beta$-D-glucoside, $25 \mathrm{mM}$ dioleoyl phosphatidylglycerol) by several cycles of sonication in a bath sonicator followed by resting at room temperature for 15-20 min. The reaction buffer was prepared as a $2 \times$ solution, containing $100 \mathrm{mM}$ imidazole $\mathrm{HCl}$, pH 6.6, $100 \mathrm{mM}$ $\mathrm{LiCl}, 25 \mathrm{mM} \mathrm{MgCl} 2,2 \mathrm{mM}$ EGTA. To the lipid micelles, $50 \mu \mathrm{l}$ of $2 \times$ reaction buffer was added, $0.2 \mu \mathrm{l}$ of $1 \mathrm{M}$ dithiothreitol, $5 \mu \mathrm{g}$ of diglycerol kinase membranes, and dilution buffer $(10 \mathrm{mM}$ imidazole, $\mathrm{pH}$ $6.6,1 \mathrm{mM}$ diethylenetriaminepentaacetic acid, $\mathrm{pH}$ 7) to a final volume of $90 \mu \mathrm{l}$. The reaction was started by adding $10 \mu \mathrm{l} 2.5 \mathrm{mM} \mathrm{[ \gamma}$ $\left.{ }^{32} \mathrm{P}\right]$ ATP solution ( $\mathrm{sp}$ act of $75,000-200,000 \mathrm{cpm} / \mathrm{nmol}$ ). The reaction was allowed to proceed at $25^{\circ} \mathrm{C}$ for $30 \mathrm{~min}$. Bligh and Dyer lipid extraction was done and a $1.5-\mathrm{ml}$ aliquot of the organic phase was dried under $\mathrm{N}_{2}$. Lipids were then resuspended in a volume of $100 \mu \mathrm{l}$ metha$\mathrm{nol} / \mathrm{chloroform}(1: 20, \mathrm{vol} / \mathrm{vol})$ and $20 \mu \mathrm{l}$ was spotted on a $20-\mathrm{cm}$ silica gel thin layer chromatography plate. Plates were developed with chloroform/acetone/methanol/acetic acid/ $\mathrm{H}_{2} \mathrm{O}$ (50:20:15:10:5), air dried, and subjected to autoradiography. The radioactive spots corresponding to phosphatidic acid and ceramide-phosphate, the phosphorylated products of DAG and ceramide, respectively, were identified by comparison to known standards. Spots were scraped into a scintillation vial containing $4 \mathrm{ml}$ of scintillation fluid and counted on a scintillation counter. Linear curves of phosphorylation were produced over a concentration range of $0-640 \mathrm{pM}$ of external standards (dioleoyl glycerol and CIII ceramide; Sigma Chemical Co.). DAG and ceramide levels were always normalized to lipid phosphate, which was measured according to the method of Rouser et al. (51). It is important to note that under these conditions, there was total conversion of ceramide and DAG to their phosphorylated products, and there was no change in the specific activity of the DAG kinase enzyme.

Unless indicated otherwise, all data shown are representative of at least three independent experiments with nearly identical results.

\section{Results}

p53-dependent apoptosis of Molt-4 leukemia cells. To examine the relationship of p53 upregulation and ceramide accumulation we decided to establish a p53-dependent system. We used actinomycin D, a DNA-intercalating antibiotic and topoisomerase modulator, which is used in the treatment of many cancers including leukemia (52). Since the ability of many chemotherapeutic agents to induce apoptosis is p53 dependent (reference 53, and references therein), we examined the effects 


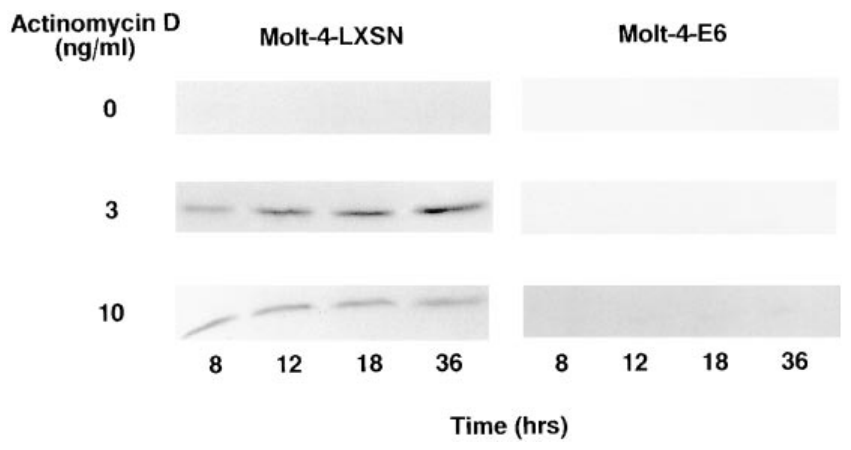

Figure 1. Actinomycin D-induced upregulation of p53. Molt-4 cells infected with either vector retrovirus LXSN (Molt-4-LXSN) or 16E6LXSN containing the sequence encoding E6 of HPV type 16 (Molt-4-E6) (45) were used. Cells growing in log phase in RPMI medium supplemented with $10 \%$ FBS and seeded at an initial concentration of $5 \times 10^{5}$ were treated with 3 or $10 \mathrm{ng} / \mathrm{ml}$ of actinomycin D for the indicated times. $2 \times 10^{6}$ cells were harvested at each time point and 553 expression was assayed by Western blotting as described in Methods.

of actinomycin D on p53 upregulation and apoptosis in Molt-4 leukemia cells.

Molt- 4 cells in the log phase of their growth were treated with actinomycin $\mathrm{D}$ for increasing durations. As shown previously in ML-1 leukemia cells (54), treatment of Molt-4 cells with actinomycin $D$ at a concentration of $3 \mathrm{ng} / \mathrm{ml}$ resulted in a significant increase in p53 levels. This upregulation was maximal by $12 \mathrm{~h}$ and was sustained up to $36 \mathrm{~h}$ (Fig. 1). At a higher concentration of $10 \mathrm{ng} / \mathrm{ml}$, maximal upregulation of p53 was achieved as early as $8 \mathrm{~h}$ after treatment (Fig. 1). Similarly, higher concentrations of actinomycin D resulted in a more rapid increase in p53 levels which was also sustained up to $36 \mathrm{~h}$ (data not shown).

Inactivation of $\mathrm{p} 53$ can be accomplished by the expression of the HPV protein, E6, which binds p53 and induces its proteolytic degradation through the ubiquitin pathway $(7,8)$. Using a retroviral vector (45), E6 from HPV type 16 was expressed in Molt-4 cells (Molt-4-E6). Expression of E6 abrogated the upregulation of $\mathrm{p} 53$ after treatment with actinomycin $\mathrm{D}$ in Molt-4-E6 cells compared with the vector Molt-4-LXSN cells (Fig. 1). To correlate the effects of actinomycin D on p53 upregulation with its effects on apoptosis, Molt- 4 cells expressing E6 were treated with increasing concentrations of actinomycin D and were compared with vector cells treated similarly. The increase in p53 levels was associated with significant cell death in vector Molt-4-LXSN cells in a dose-dependent manner. In contrast, cells expressing the E6 protein, which results in the loss of detectable p53 upregulation, were quite resistant to the cytotoxic effects of actinomycin D (Fig. $2 A$ ).

To verify that cell death was occurring through the induction of apoptosis, we assayed for cleavage of the death substrate PARP after actinomycin D treatment (46). A hallmark of apoptosis is the activation of members of the IL- $1 \beta$ converting enzyme family of proteases, now referred to as caspases (55), which results in the specific cleavage of PARP from its native $116-\mathrm{kD}$ form to an $89-\mathrm{kD}$ apoptotic fragment (56-59). Actinomycin D treatment of Molt-4 cells resulted in the specific apoptotic cleavage of PARP in the vector but not in the
E6-expressing cells (Fig. 2 B). Therefore, the inhibition of p53 by E6 protects these cells from the apoptotic effects of actinomycin D, indicating that $\mathrm{p} 53$ is required for the induction of apoptosis by actinomycin $\mathrm{D}$ at the concentrations used.

Actinomycin D induces p53-dependent ceramide accumulation. Although the effects of several chemotherapeutic agents on ceramide accumulation have been described (60-63), the effects of actinomycin D on ceramide have not been reported previously. We examined the effects of actinomycin D treatment on the endogenous levels of ceramide in Molt-4 lymphocytic leukemia cells. Treatment of Molt-4 cells with actinomycin $\mathrm{D}(10 \mathrm{ng} / \mathrm{ml})$ resulted in a time-dependent accumulation of ceramide first observed at $12 \mathrm{~h}$ after treatment (Fig. $3 \mathrm{~A}$, left).

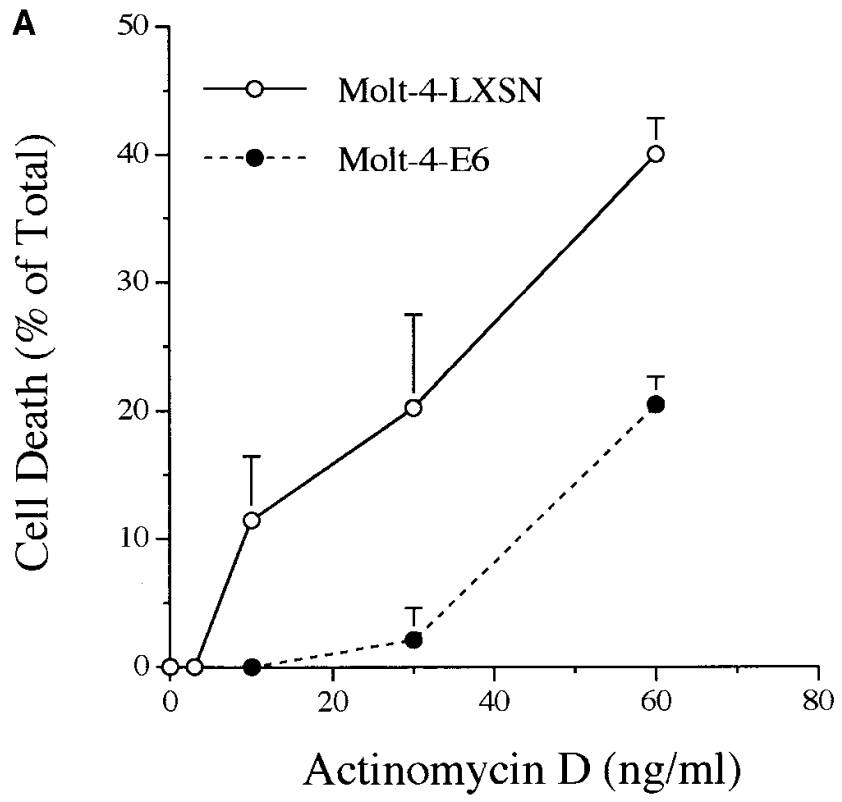

B
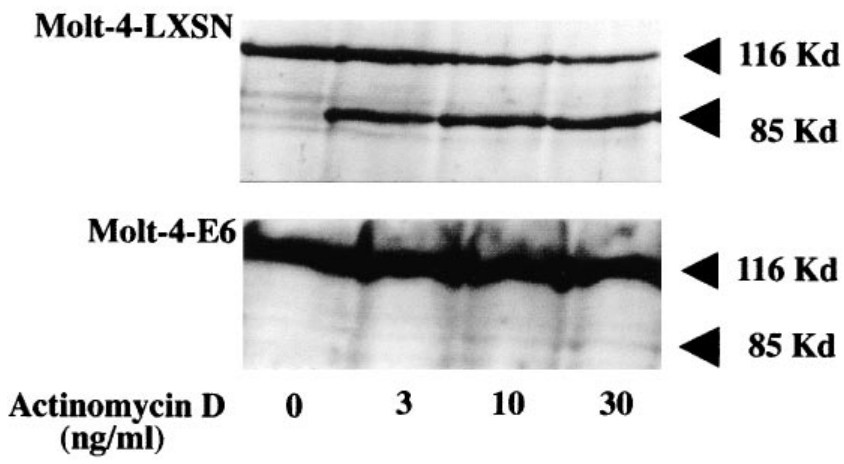

Figure 2. Actinomycin D-induced apoptosis. $(A)$ Cell death induced by actinomycin D. Molt-4-LXSN and Molt-4-E6 cells were treated as in Fig. 1 with actinomycin D concentrations of 3, 10, 30, or $60 \mathrm{ng} / \mathrm{ml}$ and dead cells, unable to exclude trypan blue, were counted at $48 \mathrm{~h}$ and are presented as a percentage of total cells counted (usually 200 cells in duplicate). (B) PARP cleavage induced by actinomycin D. Cells were treated with the indicated concentrations of actinomycin $\mathrm{D}$ for $24 \mathrm{~h}$. PARP cleavage was determined by Western blotting as described in Methods. The native fragment $(116 \mathrm{kD})$ and the cleaved (apoptotic) fragment (migrating at $\sim 85 \mathrm{kD}$ ) are indicated. Data are representative of two to three experiments. 

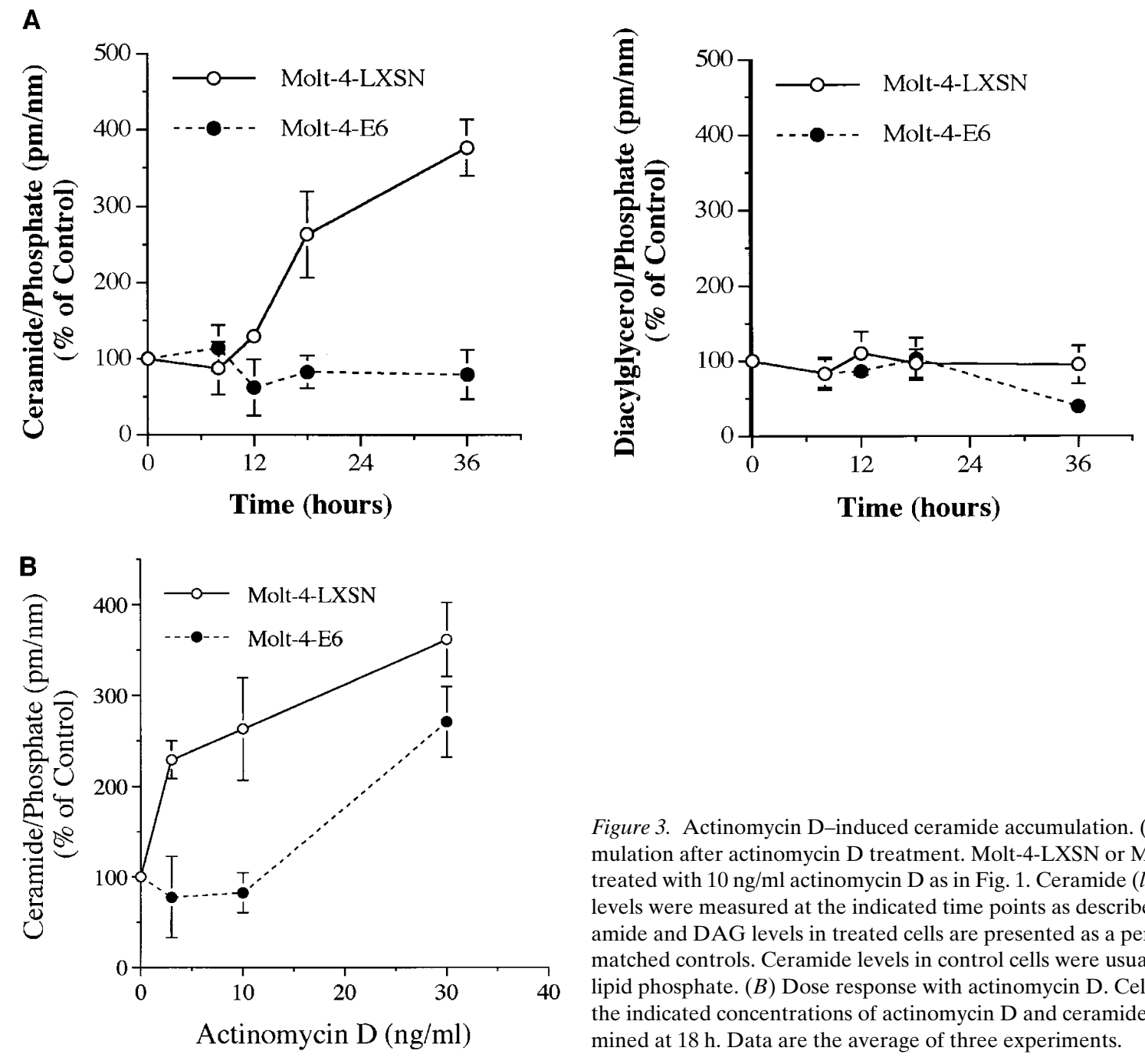

\begin{abstract}
Figure 3. Actinomycin D-induced ceramide accumulation. $(A)$ Ceramide accumulation after actinomycin D treatment. Molt-4-LXSN or Molt-4-E6 cells were treated with $10 \mathrm{ng} / \mathrm{ml}$ actinomycin D as in Fig. 1. Ceramide (left) and DAG (right) levels were measured at the indicated time points as described in Methods. Ceramide and DAG levels in treated cells are presented as a percentage of timematched controls. Ceramide levels in control cells were usually $1.8-3 \mathrm{pmol} / \mathrm{nmol}$ lipid phosphate. $(B)$ Dose response with actinomycin D. Cells were treated with the indicated concentrations of actinomycin $\mathrm{D}$ and ceramide levels were determined at $18 \mathrm{~h}$. Data are the average of three experiments.
\end{abstract}

Under those conditions, there was no change in DAG levels (Fig. $3 \mathrm{~A}$, right) indicating that the increases in ceramide are not due to a change in the specific activity of DAG kinase used in the ceramide assay as suggested recently (64). Upregulation of $\mathrm{p} 53$, which is maximal by $8 \mathrm{~h}$ at this concentration of actinomycin D (Fig. 1), preceded the increase in ceramide levels in the vector cells. This accumulation of ceramide was also dose dependent (Fig. $3 \mathrm{~B}$ ) when evaluated $18 \mathrm{~h}$ after treatment. In the Molt-4-E6 cells, the E6-mediated inhibition of p53 upregulation after treatment with similar concentrations of actinomycin D resulted in the absence of subsequent ceramide accumulation. These results suggest that an increase in p53 levels is necessary for ceramide accumulation to occur in response to actinomycin $\mathrm{D}$ at these concentrations.

$\gamma$-Irradiation causes p53-dependent cell death and ceramide accumulation. To examine whether our findings were peculiar to actinomycin $\mathrm{D}$, we examined the effects of ionizing irradiation-induced DNA damage in Molt-4 cells. Upregulation of wild-type p53 has been shown to be essential for irradiationinduced apoptosis (65). Molt-4-LXSN and Molt-4-E6 cells were irradiated at a dose of $5 \mathrm{~Gy}$. Cell death was measured 6 and $24 \mathrm{~h}$ after irradiation using trypan blue uptake. As is shown in Fig. 4 $A$, Molt-4-LXSN cells were quite sensitive to irradiation, sus- taining $>45 \%$ death at $24 \mathrm{~h}$. In contrast, Molt-4-E6 cells were significantly radioresistant with only a minimal fraction of cells dying after irradiation when compared with unirradiated controls. Measurement of intracellular ceramide levels under the same conditions revealed a 10-fold increase in Molt-4-LXSN cells by $24 \mathrm{~h}$ with no significant change in Molt-4-E6 cells (Fig. $4 \mathrm{~B}$ ). These studies suggest that genotoxic insults which function through p53 such as $\gamma$-irradiation or actinomycin D therapy induce ceramide accumulation in a p53-dependent manner.

We next developed another pair of cell lines from expression of the E6 HPV protein in L929 murine fibrosarcoma cells using the same retroviral vector (45). L929-LXSN cells infected with the vector retrovirus have growth characteristics identical to the wild-type L929 cells and contain wild-type p53 which is upregulated upon treatment with $\mathrm{TNF}_{-} \alpha$, actinomycin $\mathrm{D}$, or $\gamma$-irradiation (data not shown). L929-E6 cells infected with the retroviral construct containing the E6 gene of HPV type 16 lack functional p53 and its levels do not increase in response to the same stimuli. We exposed these two cell lines to ionizing radiation and compared their subsequent growth. As is shown in Fig. $4 C$, L929-E6 cells were significantly more resistant to ionizing radiation delivered at two doses, $10 \mathrm{~Gy}$ or 40 

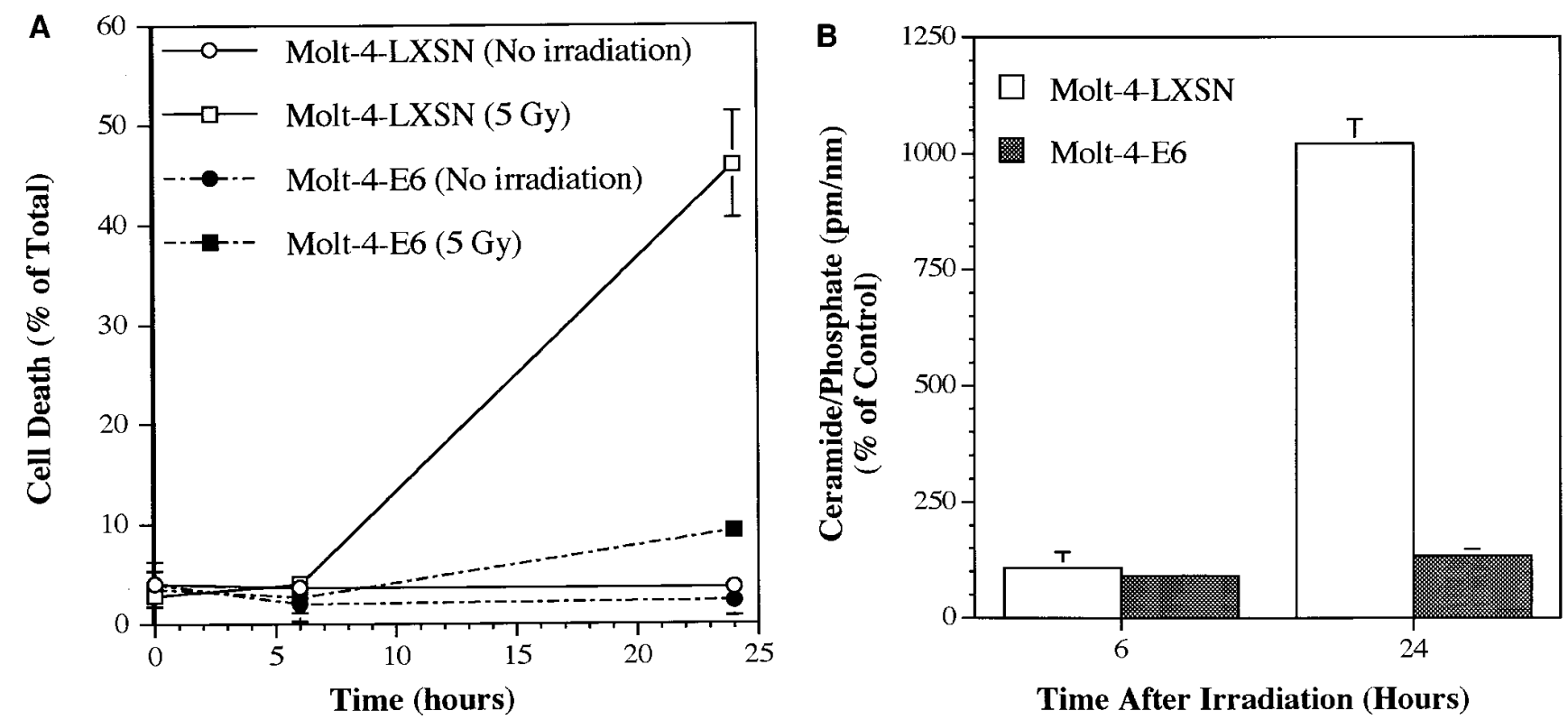

Time After Irradiation (Hours)

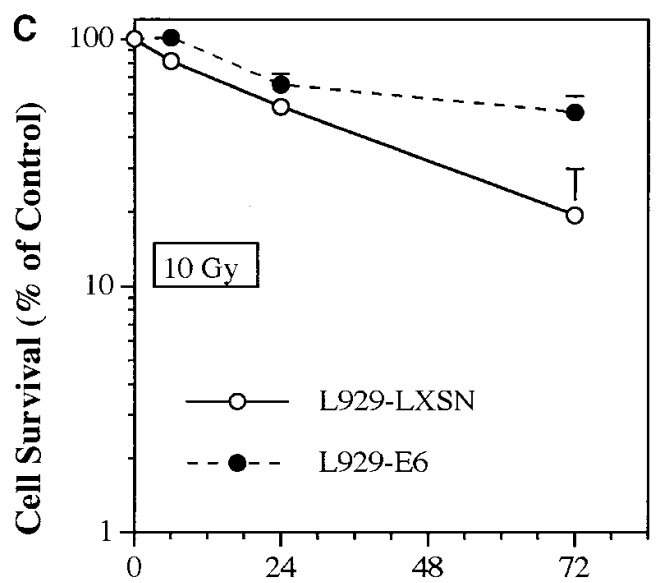

Time (hours)

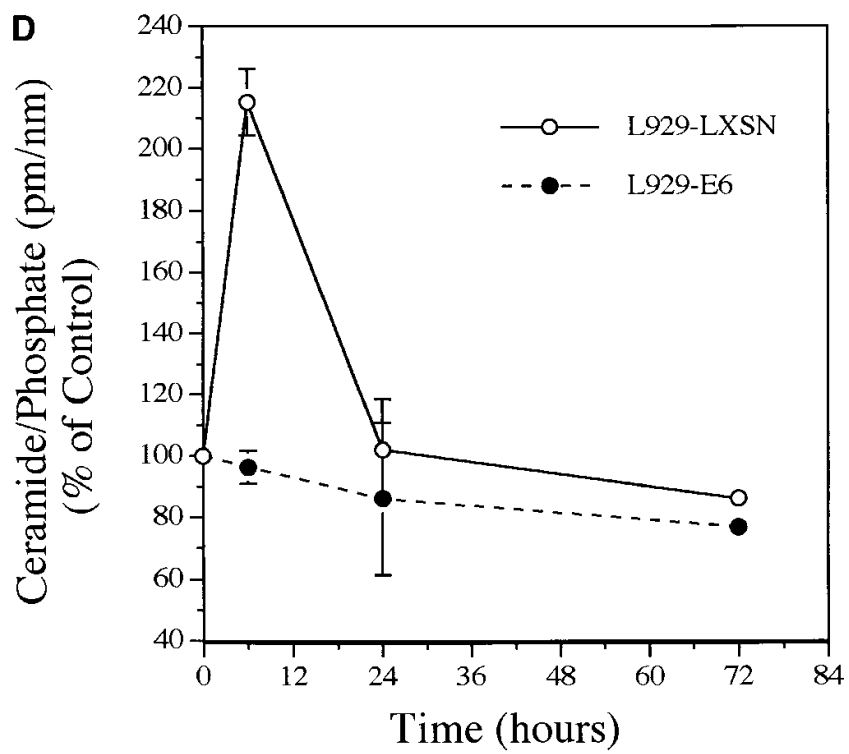

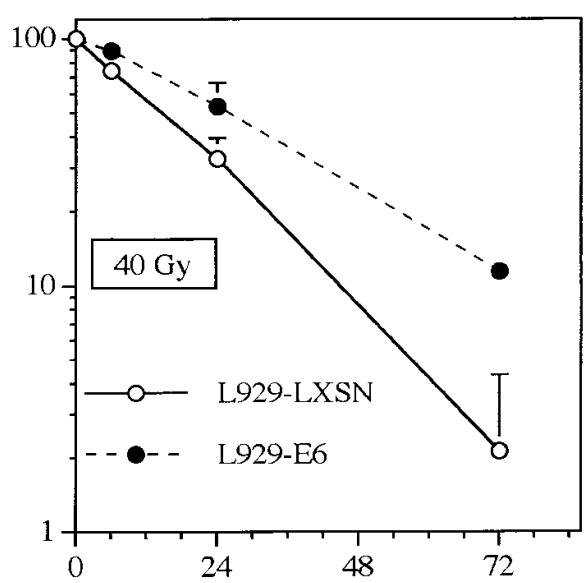

Time (hours)

Figure 4. Effects of $\gamma$-irradiation on Molt-4 and L929 cells. (A) Cytotoxic effects of $\gamma$-irradiation on Molt- 4 cells lacking or expressing p53. Molt-4-LXSN or Molt-4-E6 cells were prepared as in Fig. 1 and subsequently irradiated at a total dose of $5 \mathrm{~Gy}$. At the indicated time points, cell viability was determined using trypan blue. (B) Accumulation of ceramide in response to $\gamma$-irradiation. Molt-4 LXSN or Molt-4E6 cells were prepared as in $A$ and an aliquot of $10^{7}$ cells was removed at the indicated time points for ceramide determination as in Fig. 3. (C) Growth suppressive effects of $\gamma$-irradiation on L929 cells lacking or expressing p53. L929-LXSN or L929-E6 cells were detached from plates, counted, and then irradiated at $10 \mathrm{~Gy}$ (left) or $40 \mathrm{~Gy}$ (right). Subsequently, they were seeded at a final concentration of $10^{6}$ cells in a $25-$ $\mathrm{cm}^{2}$ flask and incubated in a $\mathrm{CO}_{2}$ incubator at $37^{\circ} \mathrm{C}$. The cells were detached at the indicated time points and the viability of both floating and adherent cells was assessed with trypan blue uptake and represented as log percentage of control cells which were similarly manipulated but not irradiated. $(D)$ Ceramide accumulation in response to $\gamma$-irradiation in L929 cells. Cells were prepared as in $C$ in triplicate flasks and then harvested at the indicated time points and ceramide was measured as above. Ceramide levels are represented as a percentage of control cells. The results are the average of two to three experiments done in duplicate. 
A

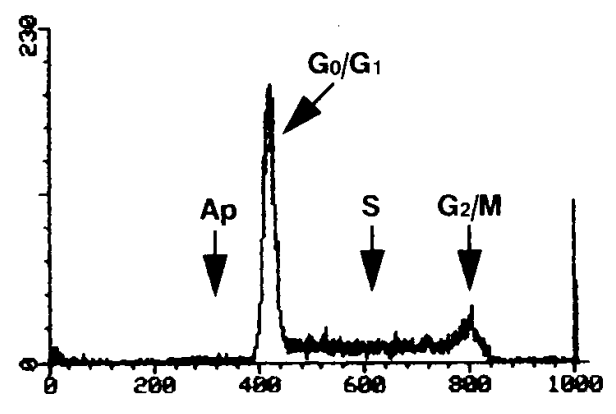

Control

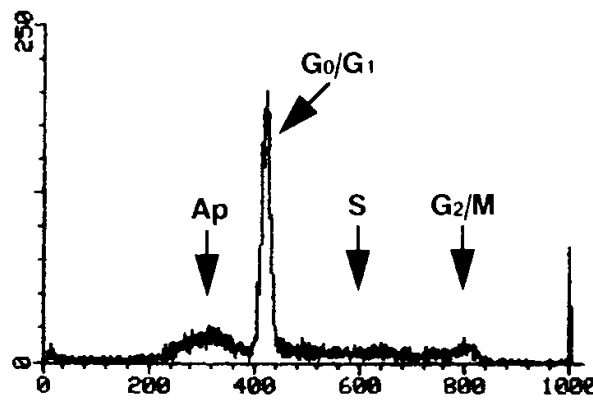

Ceramide

Figure 5. Effects of ceramide treatment on cell cycle, apoptosis, and p53. ( $A$ ) Effects of ceramide on apoptosis and cell cycle arrest in Molt- 4 cells. Molt- 4 cells were treated with $\mathrm{C}_{6}$-ceramide $(10 \mu \mathrm{M})$ or ethanol vehicle for $22 \mathrm{~h}$. The fractions of cells undergoing apoptosis $(A p)$ were $2.3 \%$ in the control cells and $24.95 \%$ in the ceramide-treated cells. Out of cycling cells, the fraction of cells in the different phases of the cell cycle were as follows. In control cells, $51 \%$ were in $\mathrm{G}_{0} / \mathrm{G}_{1}, 38.9 \%$ in $\mathrm{S}$, and $10.1 \%$

B

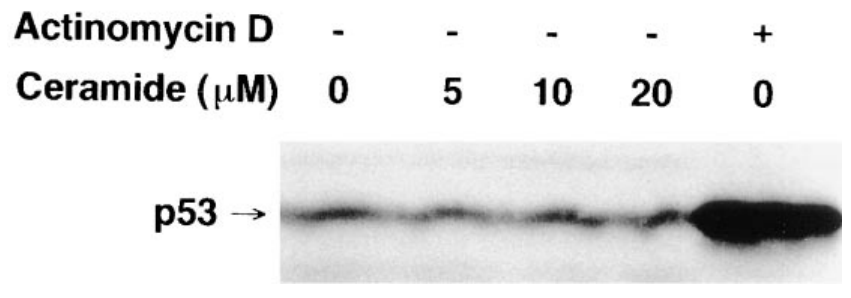
in $\mathrm{G}_{2} / \mathrm{M}$. In ceramide-treated cells, $69.3 \%$ were in $\mathrm{G}_{0} / \mathrm{G}_{1}, 24.9 \%$ in $\mathrm{S}$, and $5.8 \%$ in $\mathrm{G}_{2} /$ M. (B) Ceramide effects on p53 in Molt-4 cells. Molt-4 cells were treated with increasing concentrations of $\mathrm{C}_{6}$-ceramide or actinomycin D $100 \mathrm{ng} / \mathrm{ml}$, as indicated, for $24 \mathrm{~h}$. Expression of p53 was determined by Western blotting as in Fig. 1. Similar results were obtained after $4 \mathrm{~h}$ of ceramide treatment.

Gy, compared with L929-LXSN cells, which confirms previous findings indicating an important role for p53 in mediating the growth-suppressive effects of ionizing radiation $(65,66)$. We then measured intracellular ceramide levels after irradiation in the two cell lines. Ceramide levels were significantly elevated at $6 \mathrm{~h}$ after irradiation with $40 \mathrm{~Gy}$ in the L929-LXSN cells, which contain p53, but not in the L929-E6 cells, which lack p53 (Fig. $4 \mathrm{D}$ ). Levels returned to baseline by $24 \mathrm{~h}$ after irradiation. These results confirm our findings with Molt-4 cells and indicate that functional p53 is required for intracellular ceramide accumulation in p53-dependent pathways.

Evaluation of p53 as a downstream target for ceramide. Although the above data suggested that p53 functions upstream of ceramide, other possibilities had to be ruled out. First, the effects seen could be secondary to direct modulation of the ceramide pathway by E6 independent of its effects on p53. Second, although the kinetics of p53 upregulation and ceramide accumulation suggest that p53 levels increase first, small increases in endogenous ceramide levels, which may not be detectable by the available ceramide assays, could precede the upregulation of p53 or modulate its activity.

These possibilities led us to examine whether ceramide functioned upstream of p53 by evaluating the ability of ceramide to upregulate p53 and whether p53 was necessary for the growth-inhibiting functions of ceramide. Molt-4 cells were treated with $\mathrm{C}_{6}$-ceramide, a cell-permeable analogue of natural ceramides, at a concentration of $10 \mu \mathrm{M}$ for $22 \mathrm{~h}$. As described previously $(33,34)$, flow cytometric analysis of propidium iodide-stained cells showed the induction of specific cell cycle arrest in the $\mathrm{G}_{0} / \mathrm{G}_{1}$ phase as well as apoptosis in response to ceramide (Fig. $5 \mathrm{~A}$ ). The upregulation of p53 under these conditions was evaluated by Western blotting. Treatment of Molt- 4 cells with $\mathrm{C}_{6}$-ceramide at concentrations between 5 and $20 \mu \mathrm{M}$ for $24 \mathrm{~h}$ did not alter p53 levels when compared with untreated cells (Fig. 5 B). Similar results were seen when treat- ment was for $4 \mathrm{~h}$ (data not shown). In contrast, p53 was strongly upregulated under identical conditions with actinomycin D (Fig. 5 B). Therefore, these results show that, at biologically effective concentrations, ceramide is unable to upregulate p53.

Although p53 levels were not increased by ceramide, baseline expression of p53 could still be necessary for ceramideinduced growth suppression. To examine this possibility, we evaluated the effects of ceramide on the growth of Molt-4-E6 cells compared with the vector Molt-4-LXSN cells. Increasing concentrations of ceramide resulted in equal growth suppression of both cell lines and was not dependent on the presence of functional p53 (Fig. $6 \mathrm{~A}$ ).

Next, and in order to evaluate specifically whether the effects of ceramide on apoptosis or cell cycle arrest were p53 dependent, we analyzed the flow cytometric profiles of the Molt-4-E6 cell line compared with vector cells after ceramide treatment. As shown in Fig. 6, $B$ and $C$, neither ceramideinduced apoptosis nor cell cycle arrest was dependent on the expression of functional p53.

The ability of both ceramide $(34)$ and p53 $(67,68)$ to induce cell cycle arrest appears to be mediated through their ability to induce or maintain $\mathrm{Rb}$ in its hypophosphorylated, i.e., active, state which predominates in the $\mathrm{G}_{0} / \mathrm{G}_{1}$ phase of the cell cycle (25). Therefore, it was important to examine whether the effects of ceramide on $\mathrm{Rb}$ were dependent on p53. We examined the effects of ceramide treatment on $\mathrm{Rb}$ dephosphorylation in Molt-4-E6 cells compared with the vector cell line. As shown in Fig. $6 \mathrm{D}$, treatment of these cells with $\mathrm{C}_{6}$-ceramide resulted in equivalent dephosphorylation of $\mathrm{Rb}$, represented by the faster migrating bands on SDS-PAGE, irrespective of p53 status. Therefore, these experiments strongly suggest that p53 is not a downstream target of ceramide and is not necessary for the growth suppressive actions of ceramide.

To confirm these results using different cell lines, several 

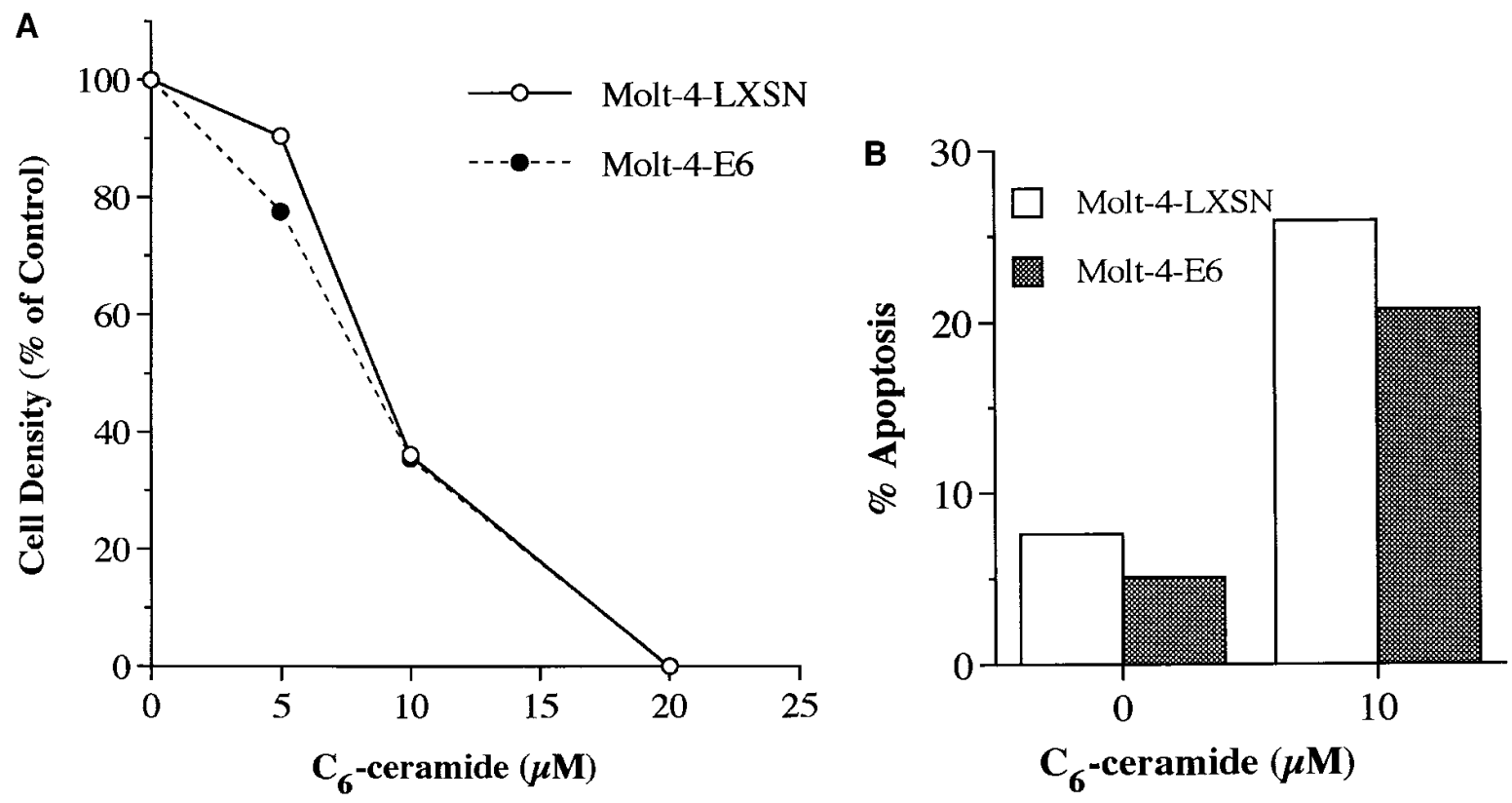

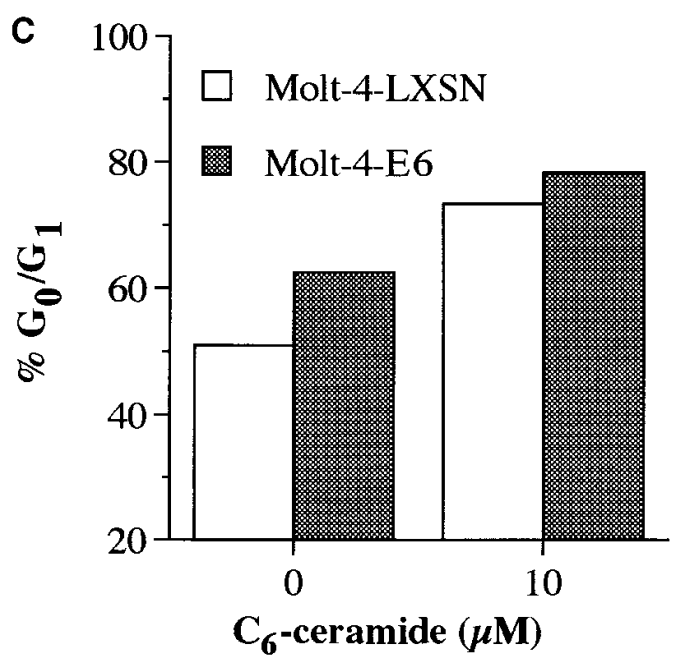

D

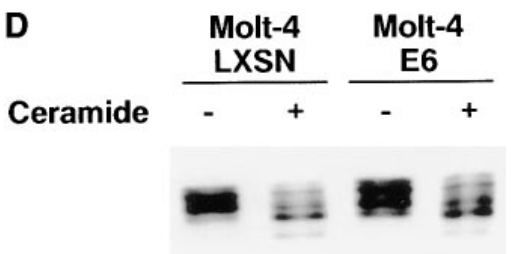

Figure 6. p53 is not necessary for ceramide-induced growth suppression. (A) Ceramide-induced growth suppression in Molt-4 cells with or without functional p53. Molt-4-LXSN and Molt4-E6 cells were seeded at $2 \times 10^{6} / 10 \mathrm{ml}$ volume in RPMI medium supplemented with $2 \%$ FBS and treated with the indicated concentrations of $\mathrm{C}_{6}$-ceramide. Viable cells were counted at $36 \mathrm{~h}$ by trypan blue exclusion and presented as a percentage of control untreated cells. $(B$ and $C$ ) Ceramide-induced apoptosis and cell cycle arrest in the presence and absence of p53. Molt-4-LXSN or Molt-4-E6 cells were treated as in Fig. $4 \mathrm{~A}$. Apoptosis and cell cycle were assayed by flow cytometry as in Fig. 4 and quantitated using the SOBR model. $(D)$ Ceramide-induced Rb dephosphorylation and the status of p53. Molt-4-LXSN or Molt-4-E6 cells were treated with $20 \mu \mathrm{M} \mathrm{C}_{6}$-ceramide for $4 \mathrm{~h}$ as indicated. The hypophosphorylated $\mathrm{Rb}$ bands migrate faster than the phosphorylated forms on SDS-PAGE. Similar results were seen at lower concentrations of $\mathrm{C}_{6}$-ceramide and longer duration of treatment. lymphocytic tumor cell lines, which differ in their p53 status, were evaluated. As shown in Fig. 7 A, HL-60 and U937 cells lack wild-type $\mathrm{p} 53$, whereas Molt-4 cells express normal levels of p53 which can be upregulated after treatment with actinomycin D. Treatment of the three cell lines with increasing concentrations of $\mathrm{C}_{6}$-ceramide resulted in comparable inhibition of cell growth $($ Fig. $7 \mathrm{~B}$ ). These findings clearly negate the possibility that p53 is required for ceramide-induced growth suppression and show that our findings in the Molt- 4 cells are applicable to other leukemic cell lines.

p53-independent ceramide accumulation. The finding of p53-dependent accumulation of ceramide in response to genotoxic damage induced by actinomycin D or $\gamma$-irradiation led us to examine whether p53 regulates ceramide accumulation in other systems where ceramide has been proposed as a central regulator of growth arrest and apoptosis. We first examined whether $\mathrm{p} 53$ was required for ceramide generation by TNF- $\alpha$. Treatment of L929 cells with TNF- $\alpha$ results in ceramide accumulation followed by cell death (69). We evaluated the upregulation of p53 in L929 cells and found that after TNF- $\alpha$ treatment p53 levels increase (Fig. $8 A$ ). As expected, TNF- $\alpha-$ induced p53 upregulation was inhibited in L929-E6 cells (Fig. 8 $A)$. Importantly, expression of E6 did not interfere with ceramide generation (Fig. 8 B, left). Indeed, ceramide accumulation occurred earlier in the E6-expressing, p53-deficient L929 cells. These results show that the ceramide response to TNF- $\alpha$ does not require functional p53. (Under these conditions, TNF- $\alpha$ did not cause significant changes in DAG levels using the same lipid samples [Fig. 8 B, right].) Furthermore, the ability of TNF- $\alpha$ to induce growth suppression was not dependent on the status of p53 (Fig. $8 \mathrm{C}$ ). Taken together, we can conclude that, in the case of TNF- $\alpha, \mathrm{p} 53$ is not required for ceramide generation, the response of cells to ceramide, or the response of cells to TNF- $\alpha$. Therefore, the major growth suppressor pathway launched by TNF- $\alpha$ is independent of $\mathrm{p} 53$.

Another ceramide-driven process occurs in serum deprivation where Molt- 4 cells accumulate massive amounts of ceramide followed by cell cycle arrest and apoptosis (33). To determine whether p53 plays any role in this system, we serum-deprived Molt-4-LXSN and Molt-4-E6 cells for $4 \mathrm{~d}$. We found that the 

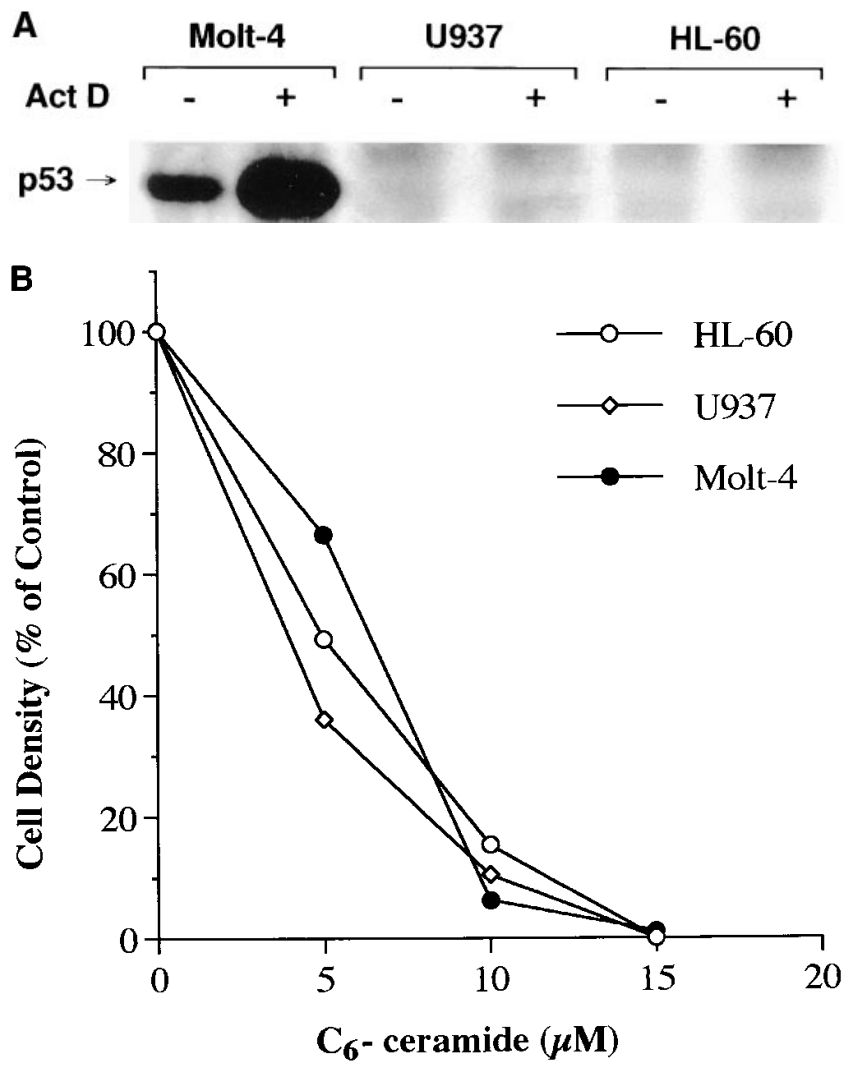

Figure 7. Effects of ceramide in leukemic cells lacking wild-type p53 expression. (A) Expression of wild-type p53 in Molt-4, U937, and HL-60 cells. Lysates from the different cell lines were prepared and Western blotting for $\mathrm{p} 53$ expression was performed in control cells or in cells treated with $0.5 \mu \mathrm{g} / \mathrm{ml}$ actinomycin D (Act $D)$. (B) Ceramideinduced growth inhibition in Molt-4, U937, and HL-60 cells. Cells were seeded at $2 \times 10^{6} / 10 \mathrm{ml}$ volume in RPMI media supplemented with $2 \%$ FBS and treated with the indicated concentrations of $\mathrm{C}_{6^{-}}$ ceramide. Viable cells were counted at $48 \mathrm{~h}$ by trypan blue exclusion and presented as a percentage of control untreated cells.

rate and degree of ceramide accumulation were equal in both cell lines (Fig. 8 D). Additionally, abrogation of p53 function in the Molt-4-E6 cells did not provide a survival advantage after serum deprivation (Fig. 8 E). In this model, the ceramide pathway also appears to be independent of the status of $\mathrm{p} 53$. Thus, in p53-independent systems, ceramide accumulation occurs irrespective of p53 induction, indicating that other pathways of ceramide generation must exist which bypass $\mathrm{p} 53$.

\section{Discussion}

Ceramide has been proposed as a mediator of apoptosis and as a coordinator of the cellular responses to stress (70). Ceramide accumulation has been observed in response to a variety of stressful stimuli including $\gamma$-irradiation, ultraviolet light, and the chemotherapeutic agents ara $\mathrm{C}$, vincristine, and daunorubicin which also upregulate p53 and cause apoptosis, cell cycle arrest, or both $(40,60-63)$. The accumulation of ceramide is not a terminal event associated with dying cells. Previous studies have shown clearly that ceramide accumulates to significant intracellular levels in viable cells overexpressing Bcl-2 (42, 61,
71). Furthermore, Bcl-2 can protect cells from apoptosis induced by exogenous synthetic ceramides $(61,71,72)$, suggesting that ceramide accumulation occurs at a point upstream of the target for Bcl-2 action.

The ability of ceramide to induce apoptosis occurs by a mechanism that can be distinguished from the effects of ceramide on cell cycle progression. In this respect, cells that overexpress Bcl-2 or in which protein kinase $\mathrm{C}$ is activated become resistant to ceramide-induced PARP cleavage and subsequent apoptosis but can still undergo ceramide-induced $\mathrm{Rb}$ dephosphorylation and cell cycle arrest $(33,35,61,73)$. Therefore, these, and possibly other, cellular factors may determine the outcome after ceramide accumulation. These distinct effects of ceramide support a role for ceramide as a downstream "sensor" of systemic or cellular stress and damage. The response of cells to the accumulated ceramide is determined by the action of other modulators or downstream regulators such as $\mathrm{Rb}$, $\mathrm{Bcl}-2$, and protein kinase $\mathrm{C}$.

A similar role has been attributed to p53 in response to stressful conditions, particularly those associated with genotoxic damage, including $\gamma$-irradiation, ultraviolet light, and chemotherapeutic agents, including actinomycin D (54) which have been shown to increase p53 levels and to require p53 for their cellular responses (54). However, the downstream effectors of p53 activation remain unknown. The cyclin-dependent kinase inhibitor p21 was proposed to be a mediator of $\mathrm{p} 53$ function (23). However, mice lacking p21 developed normally and, unlike mice lacking p53, were not susceptible to early tumorigenesis (27). These findings, along with the lack of p21 mutations in human tumors (74) suggested that other mediators might be involved. Our current study shows that ceramide functions downstream of 553 in response to low concentrations of actinomycin D and $\gamma$-irradiation. Inhibition of p53 upregulation is sufficient to prevent ceramide accumulation in this setting. One explanation for our findings is that p53 may regulate ceramide generation or removal. Therefore, in p53dependent pathways, an increase in p53 levels results in the accumulation of endogenous ceramide by mechanisms, direct or indirect, which remain to be determined. Moreover, our studies strongly indicate that $\mathrm{p} 53$ is not a downstream mediator of the growth-suppressive effects of ceramide since it was not upregulated by exogenous ceramide and it was not necessary for ceramide-induced apoptosis or cell cycle arrest.

p53-independent pathways of apoptosis have been well described. For example, apoptosis seen in mitogenically activated $\mathrm{T}$ lymphocytes from $\mathrm{p} 53$ knockout mice occurs in response to DNA damaging agents (75). Bcl-2 overexpression prevented irradiation-induced apoptosis in these cells but did not alter cell cycle arrest. This is analogous to the effects of $\mathrm{Bcl}-2$ on ceramide-treated cells (61) and suggests that ceramide may be involved in this $\mathrm{p} 53$-independent pathway. Therefore, an alternative explanation for our findings is that $\mathrm{p} 53$ and ceramide represent two pathways of stress response which get sequentially activated under certain conditions with ceramide accumulation being a common feature of both pathways. Thus, ceramide accumulates in a p53-dependent manner in p53-regulated pathways such as those launched after genotoxic damage. In cells lacking functional p53 or in p53-independent pathways, such as TNF- $\alpha$-induced apoptosis, ceramide accumulation is the predominant form of cellular response to stress or injury. This hypothesis implies that p53 may be more tightly coupled to genotoxic damage whereas ceramide may be a 

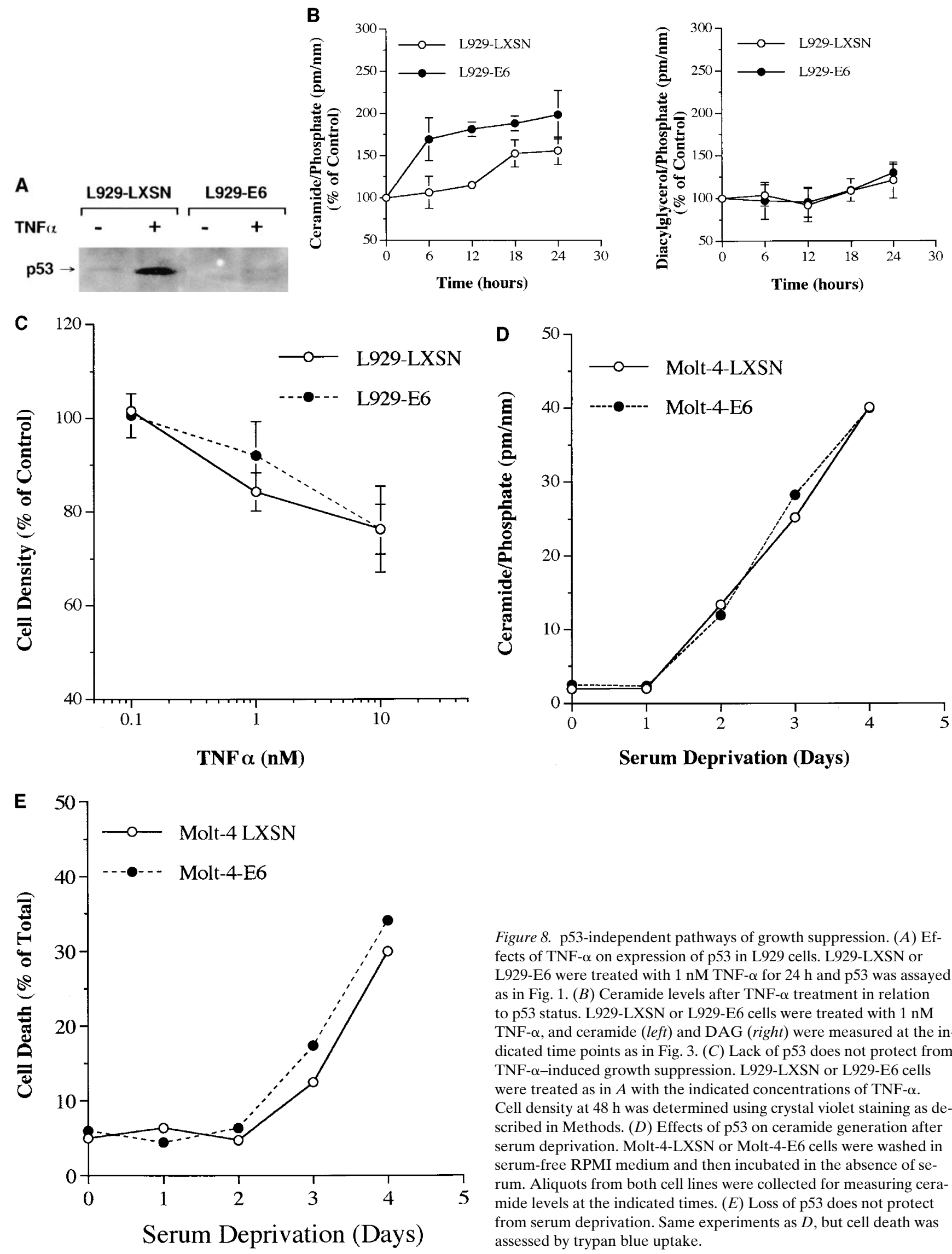

Figure 8. p53-independent pathways of growth suppression. (A) Effects of TNF- $\alpha$ on expression of p53 in L929 cells. L929-LXSN or L929-E6 were treated with $1 \mathrm{nM}$ TNF- $\alpha$ for $24 \mathrm{~h}$ and $\mathrm{p} 53$ was assayed as in Fig. 1. (B) Ceramide levels after TNF- $\alpha$ treatment in relation to p53 status. L929-LXSN or L929-E6 cells were treated with $1 \mathrm{nM}$ TNF- $\alpha$, and ceramide (left) and DAG (right) were measured at the indicated time points as in Fig. 3. $(C)$ Lack of p53 does not protect from TNF- $\alpha$-induced growth suppression. L929-LXSN or L929-E6 cells were treated as in $A$ with the indicated concentrations of TNF- $\alpha$. Cell density at $48 \mathrm{~h}$ was determined using crystal violet staining as described in Methods. $(D)$ Effects of p53 on ceramide generation after serum deprivation. Molt-4-LXSN or Molt-4-E6 cells were washed in serum-free RPMI medium and then incubated in the absence of serum. Aliquots from both cell lines were collected for measuring ceramide levels at the indicated times. $(E)$ Loss of p53 does not protect from serum deprivation. Same experiments as $D$, but cell death was assessed by trypan blue uptake. 
more general biostat for injury or stress which can be regulated by p53-dependent or -independent signals. The biochemical pathways involved in ceramide accumulation, which have been reviewed recently (76), are likely to be different in these two pathways.

Recently, acid sphingomyelinase (ASmase) was suggested as an important mediator of the apoptotic effects of ionizing irradiation (77). This conclusion was based on the resistance of some tissues, particularly lung endothelial cells, of ASmaseknockout mice to the apoptotic effects of ionizing irradiation. In comparison, apoptosis after irradiation of p53-knockout mice was only inhibited in the thymus, whereas normal apoptosis was observed in the lungs (77). These findings were interpreted to indicate that the ASmase and p53 pathways are unrelated. On the other hand, our results show that, in our model systems, radiation-induced ceramide accumulation is p53 dependent. These conclusions are not entirely inconsistent with each other. Although direct comparison with our results cannot be performed, conclusions from the ASmase knockout mice apply specifically to ASmase and not to other sources of ceramide generation. Indeed, the same group had implicated neutral sphingomyelinase in mediating the effects of ionizing irradiation on ceramide formation in a prior report (40). These different results may indicate either tissue specificity of activation of sphingomyelinases or differential activation of the two sphingomyelinases in response to irradiation. For example, the neutral sphingomyelinase may be responsible for the major peaks of ceramide accumulation in response to irradiation. Along those lines, it is interesting to note that the levels of ceramide that were observed in the ASmase-dependent system (No. 5143) were quite small (10-20\% over baseline) and occurred at very early time points compared with our results which showed up to $1000 \%$ change in ceramide levels developing over hours. In the context of our hypothesis, the tissue specificity of the response to irradiation which was observed in the knockout mice may reflect dependence on p53, e.g., in the thymus, or the lack of it, e.g., in the lung. The absence of p53 does not abrogate the ceramide response in the lung since it is activated in a p53-independent manner. Indeed, our results in Molt-4 T cells may more closely approximate apoptosis in the thymus than in endothelial cells (in which ASmase, but not $\mathrm{p} 53$, has been implicated in regulating radiation-induced apoptosis). Obviously, further studies are required to pursue the mechanisms by which p53 regulates the ceramide response.

In conclusion, the ceramide pathway appears to function downstream of $\mathrm{p} 53$, which suggests that $\mathrm{p} 53$ may regulate the ceramide pathway. These results also raise the possibility that ceramide may be a downstream mediator of p53 function. Further studies are needed to explore this hypothesis and to determine what specific effects of p53 are mediated by ceramide.

\section{Acknowledgments}

We thank Denise A. Galloway for providing the retroviral constructs; Guy G. Poirier for PARP antibody; Alicja Bielawska for $\mathrm{C}_{6}$-ceramide synthesis; James K. Schwarz, Elizabeth Selinger, Joanna Lee, Chris Gamard, and Linda Karolak for technical assistance; Gilbert Radcliff for help with the flow cytometer; and Marsha Haigood and Rita Fortune for secretarial help.

This work was supported by a National Institute of Child Health and Human Development grant and an American University of Beirut Medical Practice Plan grant (G.S. Dbaibo), and National Institutes of Health (GM 43825) and US Army (AIBS 516) grants (Y.A.
Hannun). Part of this work was done at the Research Core Facility at the American University of Beirut.

\section{References}

1. Vogelstein, B., and K.W. Kinzler. 1992. p53 function and dysfunction. Cell. 70:523-526.

2. Canman, C.E., C.Y. Chen, M.H. Lee, and M.B. Kastan. 1994. DNA damage responses: p53 induction, cell cycle perturbations, and apoptosis. Cold Spring Harb. Symp. Quant. Biol. 59:277-286.

3. Picksley, S.M., and D.P. Lane. 1994. p53 and Rb: their cellular roles. Curr. Opin. Cell Biol. 6:853-858.

4. Hollstein, M., D. Sidransky, B. Vogelstein, and C.C. Harris. 1991. p53 mutations in human cancers. Science. 253:49-53.

5. Momand, J., G.P. Zambetti, D.C. Olson, D. George, and A.J. Levine. 1992. The mdm-2 oncogene product forms a complex with the p53 protein and inhibits p53-mediated transactivation. Cell. 69:1237-1245.

6. Olson, D.C., V. Marechal, J. Momand, J. Chen, C. Romocki, and A.J. Levine. 1993. Identification and characterization of multiple $\mathrm{mdm}-2$ proteins and mdm-2-p53 protein complexes. Oncogene. 8:2353-2360.

7. Scheffner, M., B.A. Werness, J.M. Huibregtse, A.J. Levine, and P.M. Howley. 1990. The E6 oncoprotein encoded by human papillomavirus types 16 and 18 promotes the degradation of p53. Cell. 63:1129-1136.

8. Scheffner, M., J.M. Huibregtse, R.D. Vierstra, and P.M. Howley. 1993. The HPV-16 E6 and E6-AP complex functions as a ubiquitin-protein ligase in the ubiquitination of p53. Cell. 75:495-505.

9. Picksley, S.M., and D.P. Lane. 1993. The p53-mdm2 autoregulatory feedback loop: a paradigm for the regulation of growth control by p53? Bioessays. 15:689-690.

10. Marchetti, A., F. Buttitta, S. Pellegrini, G. Merlo, A. Chella, C.A. Angeletti, and G. Bevilacqua. 1995. mdm2 gene amplification and overexpression in non-small cell lung carcinomas with accumulation of the p53 protein in the absence of p53 gene mutations. Diagn. Mol. Pathol. 4:93-97.

11. McCann, A.H., A. Kirley, D.N. Carney, N. Corbally, H.M. Magee, G. Keating, and P.A. Dervan. 1995. Amplification of the $M D M 2$ gene in human breast cancer and its association with $M D M 2$ and 553 protein status. Br. J. Cancer. 71:981-985.

12. Reifenberger, G., L. Liu, K. Ichimura, E.E. Schmidt, and V.P. Collins. 1993. Amplification and overexpression of the MDM2 gene in a subset of human malignant gliomas without p53 mutations. Cancer Res. 53:2736-2739.

13. Kuerbitz, S.J., B.S. Plunkett, W.V. Walsh, and M.B. Kastan. 1992. Wildtype p53 is a cell cycle checkpoint determinant following irradiation. Proc. Natl. Acad. Sci. USA. 89:7491-7495.

14. Hartwell, L.H., and M.B. Kastan. 1994. Cell cycle control and cancer. Science. 266:1821-1828.

15. Atadja, P., H. Wong, I. Garkavtsev, C. Veillette, and K. Riabowol. 1995 Increased activity of $\mathrm{p} 53$ in senescing fibroblasts. Proc. Natl. Acad. Sci. USA. 92:8348-8352.

16. Lowe, S.W., H.E. Ruley, T. Jacks, and D.E. Housman. 1993. p53-dependent apoptosis modulates the cytotoxicity of anticancer agents. Cell. 74:957-967.

17. Debbas, M., and E. White. 1993. Wild-type p53 mediates apoptosis by E1A, which is inhibited by E1B. Genes Dev. 7:546-554.

18. Zhan, Q., I. Bae, M.B. Kastan, and A.J. Fornace, Jr. 1994. The p53dependent gamma-ray response of GADD45. Cancer Res. 54:2755-2760.

19. Smith, M.L., I.-T. Chen, Q. Zhan, I. Bae, C.-Y. Chen, T.M. Gilmer, M.B. Kastan, P.M. O'Connor, and A.J. Fornace, Jr. 1994. Interaction of the p53-regulated protein Gadd45 with proliferating cell nuclear antigen. Science. 266:1376-1380.

20. Mummenbrauer, T., F. Janus, B. Müller, L. Wiesmüller, W. Deppert, and F. Grosse. 1996. p53 protein exhibits $3^{\prime}$-to-5' exonuclease activity. Cell. 85: 1089-1099.

21. Lane, D.P. 1992. p53, guardian of the genome. Nature. 358:15-16.

22. El-Deiry, W.S., T. Tokino, V.E. Velculescu, D.B. Levy, R. Parsons, J.M. Trent, D. Lin, W.E. Mercer, K.W. Kinzler, and B. Vogelstein. 1993. WAF1, a potential mediator of p53 tumor suppression. Cell. 75:817-825.

23. El-Deiry, W.S., J.W. Harper, P.M. O'Connor, V.E. Velculescu, C.E. Canman, J. Jackman, J.A. Pietenpol, M. Burrell, D.E. Hill, Y. Wang, et al. 1994. WAF1/CIP1 is induced in p53-mediated G1 arrest and apoptosis. Cancer Res. 54:1169-1174.

24. Harper, J.W., G.R. Adami, N. Wei, K. Keyomarsi, and S.J. Elledge. 1993. The p21 Cdk-interacting protein Cip1 is a potent inhibitor of G1 cyclindependent kinases. Cell. 75:805-816.

25. Weinberg, R.A. 1995. The retinoblastoma protein and cell cycle control. Cell. 81:323-330.

26. Brugarolas, J., C. Chandrasekaran, J.I. Gordon, D. Beach, T. Jacks, and G.J. Hannon. 1995. Radiation-induced cell cycle arrest compromised by $\mathrm{p} 21$ deficiency. Nature. 377:552-557.

27. Deng, C., P. Zhang, J.W. Harper, S.J. Elledge, and P. Leder. 1995. Mice lacking p21 CIPI/WAFI undergo normal development, but are defective in G1 checkpoint control. Cell. 82:675-684.

28. Caelles, C., A. Helmberg, and M. Karin. 1994. p53-dependent apoptosis 
in the absence of transcriptional activation of p53-target genes. Nature. 370: 220-223.

29. Shen, Y., and T. Shenk. 1994. Relief of p53-mediated transcriptional repression by the adenovirus E1B $19-\mathrm{kD}$ protein or the cellular Bcl-2 protein. Proc. Natl. Acad. Sci. USA. 91:8940-8944.

30. Sabatini, P., S. Chiou, L. Rao, and E. White. 1995. Modulation of p53mediated transcriptional repression and apoptosis by the adenovirus E1B $19 \mathrm{~K}$ protein. Mol. Cell. Biol. 15:1060-1070.

31. Hannun, Y.A. 1994. The sphingomyelin cycle and the second messenger function of ceramide. J. Biol. Chem. 269:3125-3128.

32. Okazaki, T., A. Bielawska, R.M. Bell, and Y.A. Hannun. 1990. Role of ceramide as a lipid mediator of $1 \alpha, 25$-dihydroxyvitamin $\mathrm{D}_{3}$-induced HL-60 cell differentiation. J. Biol. Chem. 265:15823-15831.

33. Jayadev, S., B. Liu, A.E. Bielawska, J.Y. Lee, F. Nazaire, M.Y.U. Pushkareva, L.M. Obeid, and Y.A. Hannun. 1995. Role for ceramide in cell cycle arrest. J. Biol. Chem. 270:2047-2052.

34. Dbaibo, G.S., M.Y. Pushkareva, S. Jayadev, J.K. Schwarz, J.M. Horowitz, L.M. Obeid, and Y.A. Hannun. 1995. Retinoblastoma gene product as a downstream target for a ceramide-dependent pathway of growth arrest. Proc. Natl. Acad. Sci. USA. 92:1347-1351.

35. Obeid, L.M., C.M. Linardic, L.A. Karolak, and Y.A. Hannun. 1993. Programmed cell death induced by ceramide. Science. 259:1769-1771.

36. Venable, M.E., J.Y. Lee, M.J. Smyth, A. Bielawska, and L.M. Obeid. 1995. Role of ceramide in cellular senescence. J. Biol. Chem. 270:30701-30708.

37. Kim, M., C. Linardic, L. Obeid, and Y. Hannun. 1991. Identification of sphingomyelin turnover as an effector mechanism for the action of tumor necrosis factor $\alpha$ and $\gamma$-interferon: specific role in cell differentiation. J. Biol. Chem. 266:484-489.

38. Cifone, M.G., R. De Maria, P. Roncaioli, M.R. Rippo, M. Azuma, L.L. Lanier, A. Santoni, and R. Testi. 1994. Apoptotic signaling through CD95 (Fas/ Apo-1) activates an acidic sphingomyelinase. J. Exp. Med. 180:1547-1552.

39. Tepper, C.G., S. Jayadev, B. Liu, A. Bielawska, R. Wolff, S. Yonehara, Y.A. Hannun, and M.F. Seldin. 1995. Role of ceramide as an endogenous mediator of Fas-induced cytotoxicity. Proc. Natl. Acad. Sci. USA. 92:8443-8447.

40. Haimovitz-Friedman, A., C.C. Kan, D. Ehleiter, R.S. Persaud, M. McLoughlin, Z. Fuks, and R.N. Kolesnick. 1994. Ionizing radiation acts on cellular membranes to generate ceramide and initiate apoptosis. J. Exp. Med. 180: $525-535$

41. Smyth, M.J., D.K. Perry, J. Zhang, G.G. Poirier, Y.A. Hannun, and L.M. Obeid. 1996. prICE: a downstream target for ceramide-induced apoptosis and for the inhibitory action of bcl-2. Biochem. J. 316:25-28.

42. Dbaibo, G.S., D.K. Perry, C.J. Gamard, R. Platt, G.G. Poirier, L.M. Obeid, and Y.A. Hannun. 1997. Cytokine response modifier A (CrmA) inhibits ceramide formation in response to tumor necrosis factor (TNF) $\alpha$ : CrmA and Bcl-2 target distinct components in the apoptotic pathway. J. Exp. Med. 185: 481-490.

43. Hannun, Y.A., and C.M. Linardic. 1993. Sphingolipid breakdown products: anti-proliferative and tumor-suppressor lipids. Biochim. Biophys. Acta Bio-Membr. 1154:223-236.

44. Pushkareva, M., L.M. Obeid, and Y.A. Hannun. 1995. Ceramide: an endogenous regulator of apoptosis and growth suppression. Immunol. Today. 16: 294-297.

45. Foster, S.A., G.W. Demers, B.G. Etscheid, and D.A. Galloway. 1994. The ability of human papillomavirus E6 proteins to target p53 for degradation in vivo correlates with their ability to abrogate actinomycin D-induced growth arrest. J. Virol. 68:5698-5705.

46. Kaufmann, S.H., S. Desnoyers, Y. Ottaviano, N.E. Davidson, and G.G. Poirier. 1993. Specific proteolytic cleavage of poly(ADP-ribose) polymerase: an early marker of chemotherapy-induced apoptosis. Cancer Res. 53:3976-3985.

47. Bielawska, A., C.M. Linardic, and Y.A. Hannun. 1992. Ceramide-mediated biology: determination of structural and stereospecific requirements through the use of $\mathrm{N}$-acyl-phenylaminoalcohol analogs. J. Biol. Chem. 267: $18493-18497$.

48. Bielawska, A., H.M. Crane, D. Liotta, L.M. Obeid, and Y.A. Hannun. 1993. Selectivity of ceramide-mediated biology: lack of activity of erythro-dihydroceramide. J. Biol. Chem. 268:26226-26232

49. Bligh, E.G., and W.J. Dyer. 1959. A rapid method of total lipid extraction and purification. Can. J. Biochem. Phys. 37:911-917.

50. Preiss, J., C.R. Loomis, W.R. Bishop, R. Stein, J.E. Niedel, and R.M. Bell. 1986. Quantitative measurement of sn-1,2-diacylglycerols present in platelets, hepatocytes, and ras- and sis-transformed normal rat kidney cells. J. Biol. Chem. 261:8597-8600.

51. Rouser, G., S. Fleischer, and A. Yamamoto. 1970. Two dimensional thin layer chromatographic separation of polar lipids and determination of phospholipids by phosphorus analysis of spots. Lipids. 5:494-496.

52. Trask, D.K., and M.T. Muller. 1988. Stabilization of type I topoisomerase-DNA covalent complexes by actinomycin D. Proc. Natl. Acad. Sci. USA. 85:1417-1421.
53. Levine, A.J. 1997. p53, the cellular gatekeeper for growth and division. Cell. 88:323-331.

54. Kastan, M.B., O. Onyekwere, D. Sidransky, B. Vogelstein, and R.W. Craig. 1991. Participation of p53 protein in the cellular response to DNA damage. Cancer Res. 51:6304-6311.

55. Alnemri, E.S., D.J. Livingston, D.W. Nicholson, G. Salvesen, N.A. Thornberry, W.W. Wong, and J. Yuan. 1996. Human ICE/CED-3 protease nomenclature. Cell. 87:171.

56. Lazebnik, Y.A., S.H. Kaufmann, S. Desnoyers, G.G. Poirier, and W.C Earnshaw. 1994. Cleavage of poly(ADP-ribose) polymerase by a proteinase with properties like ICE. Nature. 371:346-347.

57. Fernandes-Alnemri, T., G. Litwack, and E.S. Alnemri. 1994. CPP32, a novel human apoptotic protein with homology to Caenorhabditis elegans cell death protein Ced-3 and mammalian interleukin-1 $\beta$-converting enzyme. $J$. Biol. Chem. 269:30761-30764.

58. Tewari, M., L.T. Quan, K. O'Rourke, S. Desnoyers, Z. Zeng, D.R. Beidler, G.G. Poirier, G.S. Salvesen, and V.M. Dixit. 1995. Yama/CPP32 $\beta$, a mammalian homolog of CED-3, is a CrmA-inhibitable protease that cleaves the death substrate poly(ADP-ribose) polymerase. Cell. 81:801-809.

59. Nicholson, D.W., A. Ali, N.A. Thornberry, J.P. Vaillancourt, C.K. Ding, M. Gallant, Y. Gareau, P.R. Griffin, M. Labele, Y.A. Lazebnik, et al. 1995. Identification and inhibition of the ICE/CED-3 protease necessary for mammalian apoptosis. Nature. 376:37-43.

60. Strum, J.C., G.W. Small, S.B. Pauig, and L.W. Daniel. 1994. 1- $\beta$-D-arabinofuranosylcytosine stimulates ceramide and diglyceride formation in HL-60 cells. J. Biol. Chem. 269:15493-15497.

61. Zhang, J., N. Alter, J.C. Reed, C. Borner, L.M. Obeid, and Y.A. Hannun. 1996. Bcl-2 interrupts the ceramide-mediated pathway of cell death. Proc. Natl. Acad. Sci. USA. 93:5325-5328.

62. Bose, R., M. Verheij, A. Haimovitz-Friedman, K. Scotto, Z. Fuks, and RN. Kolesnick. 1996. Ceramide synthase mediates daunorubicin-induced apoptosis: an alternative mechanism for generating death signals. Cell. 82:405-414.

63. Jaffrézou, J., T. Levade, A. Bettaïeb, N. Andrieu, C. Bezombes, N Maestre, S. Vermeersch, A. Rousse, and G. Laurent. 1996. Daunorubicininduced apoptosis: triggering of ceramide generation through sphingomyelin hydrolysis. EMBO (Eur. Mol. Biol. Organ.) J. 15:2417-2424.

64. Watts, J.D., M. Gu, A.J. Polverino, S.D. Patterson, and R. Aebersold. 1997. Fas-induced apoptosis of T cells occurs independently of ceramide generation. Proc. Natl. Acad. Sci. USA. 94:7292-7296.

65. Lowe, S.W., E.M. Schmitt, S.W. Smith, B.A. Osborne, and T. Jacks. 1993. p53 is required for radiation-induced apoptosis in mouse thymocytes. $\mathrm{Na}$ ture. 362:847-849.

66. Tsang, N.M., H. Nagasawa, C. Li, and J.B. Little. 1995. Abrogation of p53 function by transfection of HPV16 E6 gene enhances the resistance of human diploid fibroblasts to ionizing radiation. Oncogene. 10:2403-2408.

67. Slebos, R.J., M.H. Lee, B.S. Plunkett, T.D. Kessis, B.O. Williams, T. Jacks, L. Hedrick, M.B. Kastan, and K.R. Cho. 1994. p53-dependent G1 arrest involves pRB-related proteins and is disrupted by the human papillomavirus 16 E7 oncoprotein. Proc. Natl. Acad. Sci. USA. 91:5320-5324.

68. White, E. 1994. p53, guardian of Rb. Nature. 371:21-22.

69. Jayadev, S., H.L. Hayter, N. Andrieu, C.J. Gamard, B. Liu, R. Balu, M. Hayakawa, F. Ito, and Y.A. Hannun. 1997. Phospholipase A2 is necessary for tumor necrosis factor $\alpha$-induced ceramide generation in L929 cells. J. Biol. Chem. 272:17196-17203

70. Hannun, Y.A. 1996. Functions of ceramide in coordinating cellular responses to stress. Science. 274:1855-1859.

71. Allouche, M., A. Bettaieb, C. Vindis, A. Rousse, C. Grignon, and G. Laurent. 1997. Influence of Bcl-2 overexpression on the ceramide pathway in daunorubicin-induced apoptosis of leukemic cells. Oncogene. 14:1837-1845.

72. Martin, S.J., S. Takayama, A.J. McGahon, T. Miyashita, J. Corbeil, R.N. Kolesnick, J.C. Reed, and D.R. Green. 1995. Inhibition of ceramide-induced apoptosis by Bcl-2. Cell Death Differ. 2:253-257.

73. Jarvis, W.D., F.A. Fornari, Jr., J.L. Browning, D.A. Gewirtz, R.N. Kolesnick, and S. Grant. 1994. Attenuation of ceramide-induced apoptosis by diglyceride in human myeloid leukemia cells. J. Biol. Chem. 269:31685-31692.

74. Shiohara, M., W.S. El-Deiry, M. Wada, T. Nakamaki, S. Takeuchi, R. Yang, D.L. Chen, B. Vogelstein, and H.P. Koeffler. 1994. Absence of WAF1 mutations in a variety of human malignancies. Blood. 84:3781-3784.

75. Strasser, A., A.W. Harris, T. Jacks, and S. Cory. 1994. DNA damage can induce apoptosis in proliferating lymphoid cells via p53-independent mechanisms inhibitable by Bcl-2. Cell. 79:329-339.

76. Hannun, Y.A. 1997. Sphingolipid-Mediated Signal Transduction. R.G. Landes Company, Austin, TX. 188 pp.

77. Santana, P., L.A. Peña, A. Haimovitz-Friedman, S. Martin, D. Green, M. McLoughlin, C. Cordon-Cardo, E.H. Schuchman, Z. Fuks, and R Kolesnick. 1996. Acid sphingomyelinase-deficient human lymphoblasts and mice are defective in radiation-induced apoptosis. Cell. 86:189-199. 